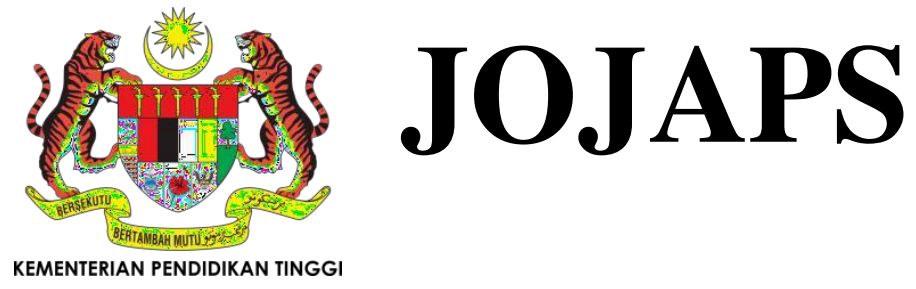

eISSN 2504-8457

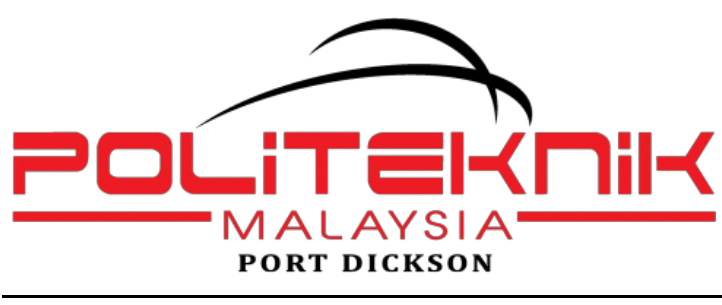

Journal Online Jaringan Pengajian Seni Bina (JOJAPS)

\title{
The Influence of Motivation, Discipline, Work Environment, Education and Workshop Towards Bipedal Civil Servants' Performance in Aceh Province
}

\author{
Josi Farmiati ${ }^{\text {a* }}$, Zahriatul Aini ${ }^{\text {a }}$, Rahmat Arfan ${ }^{\mathrm{b}}$, Hamdani $^{\mathrm{b}}$, Dahlia ${ }^{\mathrm{c}}$ \\ ${ }^{a}$ Department of Office Administration, Politeknik Kutaraja, Banda Aceh, Indonesia \\ ${ }^{b}$ Department of Public Financial Management, Politeknik Kutaraja, Banda Aceh, Indonesia \\ ${ }^{c}$ Department of Financial Analysis, Politeknik Kutaraja, Banda Aceh, Indonesia \\ jfarmiati@gmail.com
}

\begin{abstract}
Human resource (HR), in governmental organization which is familiar with civil servants, are expected to be able to explode their energy, thoughts, talents, and creativity to achieve organizational goals. Employee work results are the results of quality and quantity of work achieved by an employee in carrying out the duty in accordance with the responsibilities given. To assess the quality of human resources, it can be measured by employee performance. Various problems found in the field showed that the factors such work motivation, discipline, work environment, education and training (DIKLAT) of BAPEDAL Aceh Province employees need to be further improved so that overall employee performance becomes better, therefore further function and the duty of BAPEDAL can be carried out based on the objectives expected by the agency. This research was conducted for the Influence of Motivation, Discipline, Work Environment, Education and workshop towards the Performance of Civil Servants of the Environmental Impact Management Agency (Bapedal) of Aceh Province. The results of the study proved that simultaneously work motivation, work discipline, work environment and training significantly influence Beta Y (civil servants' performance)
\end{abstract}

(C) 2012 Published by JOJAPS Limited.

Key-word: - motivation, discipline, work environment, education and workshop

\section{Introduction}

The study of motivation is an attempt to get the answers of all complex human behavior which is related to employees' work. Human Resources is a very important company asset in an organization or company activities. The fundamental reason said so is both to face the demands of today's duty and to answer future challenges (Hutajulu and Supriyanto, 2013). Every employee often has motivation in accordance with his obsession, some of them oriented to income and some are oriented to the opportunity to get a career in accordance with the reality, yet the leadership control is needed, therefore whatever happens will not affect the agency goals or work unit. However, there are other aspects that also affect employees performance, namely discipline. An employee who has a high level of discipline will work well even without being supervised by supervisor A disciplined employee will not corrupt time to do useless things. How important discipline for civil servant is, makes government through the Minister of Administrative Reform always strives for employees to always increase their level of discipline which is also an effort to improve their work performance. The problems faced by BAPEDAL Aceh Province in terms of employee discipline are, there are still many employees who do not take part in the morning ceremony, employees often spend time off, employees are often late and go home earlier. Besides the motivation and discipline, the other influential factors are environmental conditions factors and workshop and education. work environment has an influence in an agency to run the duty assigned, which is finally affects the employee's performance. A good work environment and satisfying will certainly improve employees' performance. So they can complete the duty well and full of responsibility. Vice versa if the work environment is less satisfactory can cause employees to work in a less calm situation, the more level of mistakes they make. 
Education and workshops are factors that can affect employees' performance. Through this workshop, employees can get help to their work and improve their performance. Workshop for employees is a process of teaching certain knowledge and expertise and attitudes so that employees become more skilled and able to carry out their responsibilities better, in accordance with their respective capacities. By giving workshop to employees automatically, it will advance their knowledge and improve the results of their work which so far is still very bad furthermore, it will improve their work performance in agency records. If this problem was ignored time by time, the performance of civil servants is going to be worse. Based on the problems found in the field, it shows that the factors such work motivation, discipline, work environment, education and workshop of Aceh Province BAPEDAL employees need to be improved so that employee performance is going to be better and furthermore, the function and the duty of BAPEDAL can be done based on the goals expected.

\section{Methodology}

\subsection{Factors analysis}

Factor analysis is one of a multivariate statistic technique. The purpose is to group the data into some correlated groups among variables. In order to factors analysis could be conducted, the first thing need to do is determining the score of Barlett Test of Sphericity, which is used to see whether there is significant correlation among variables and secondly is Keiser-Meyers-Oklin (KMO), which is used to measure the number of sample by comparing the number of correlation coefficient observed by its partial coefficient correlation.

According to Wibisono (2003sustainability criteria in analysis factors are:

$\checkmark$ If $\mathrm{KMO}=0,9$ it is very satisfied

$\checkmark$ If $\mathrm{KMO}=0,8$ it is satisfied

$\checkmark$ If $\mathrm{KMO}=0,7$ medium price

$\checkmark$ If $\mathrm{KMO}=0,6$ it is enough

$\checkmark$ If $\mathrm{KMO}=0,5$ it is satisfied enough

$\checkmark$ If KMO less than 0,5 it cannot be accepted (rejected)

\subsection{Multiple Linear Regression analysis}

To test the hypothesis this study conducted multiple regression where it could be seen that $\mathrm{Y}$ (civil servants' performance) quantitatively from every variable $\mathrm{X}$ as the pattern bellow;

Information:

$$
\mathrm{Y}=\mathrm{a}+\mathrm{b}_{1} \mathrm{X}_{1}+\mathrm{b}_{2} \mathrm{X}_{2}+\mathrm{b}_{3} \mathrm{X}_{3}+\mathrm{b}_{4} \mathrm{X}_{4}+\mathrm{e}
$$

$\mathrm{Y}=$ civil servants' performance

$\mathrm{b}_{1}=$ regression coefficient for each variable $\left(\mathrm{X}_{1}, \mathrm{X}_{2}, \mathrm{X}_{3}\right.$, dan $\left.\mathrm{X}_{4}\right)$

$\mathrm{X}_{1}=$ work motivation

$\mathrm{X}_{2}=$ work discipline

$\mathrm{X}_{3}=$ work environment

$\mathrm{X}_{4}=$ workshop

$\mathrm{a}=$ constant

$\mathrm{e}=$ Std. error

the calculation of regression will show functional correlation between 'dependent variable $(\mathrm{Y})$ and independent variables $\left(\mathrm{X}_{1}, \mathrm{X}_{2}\right.$, $\left.\mathrm{X}_{3}, \mathrm{X}_{4}\right)$. To calculate the correlation of those variables totally, it used correlation analysis by finding the correlations coefficient(R), however to see how much influence independent variable to dependent variables and civil servants' performance totally, it used determination coefficient $(\mathrm{R})$.

\subsection{Determination coefficient $\left(\mathbf{R}^{2}\right)$}

Determination coefficient is used to measure how far model ability explain dependent variable variations. Its score is zero and one. Less $\mathrm{R}$ score stated that the ability of independent variables in explaining a very limited dependent variable. The score which is almost one stated that independent variables give almost the whole information needed to predict dependent variable variation. Nilai yang mendekati satu berarti variabel-variabel independen memberikan hampir semua informasi yang dibutuhkan untuk memprediksi variasi variabel dependen.

\subsection{Significant Simultan Test (F test) and Parsial Test (t test)}

In testing the level significance of work motivation, leadership, work discipline, work environment and workshop variables totally towards civil servants' performance, it needs F Test. Meanwhile, partially whether those variables has significant influence towards civil servant' performance, it uses t-test (statistic-t test) with Confidence Interval $95 \%$.

\subsection{Population and sample}

This study applied purposive method. It was selected by researcher obviously and it was relevant to this study. There would be 100 BAPEDAL civil servants of Aceh province, the results were expected to give a right description from the population studied. 
2. LITERATURE STUDIES

\section{1 work motivation}

According to Davis and Newstrom (1995) "Motivation is defined as the power of impulse to take an action". Furthermore Danim (2004) argues that: Motivation as any power that arises from within an individual to achieve certain goals or benefits in the world of work or in the yard of life in general.

\subsection{Discipline}

Discipline in an agency can be enforced if most of the rules are obeyed by most employees. In practice if an agency has been able to make the most of the regulations obeyed by most of its employees, in fact discipline can be enforced. Form of discipline can be reflected in the atmosphere, the following:

1. High employee awareness of agency achievements

2. High enthusiasm and enthusiasm for work and initiative of employees in doing work.

3. The magnitude of the employee's sense of responsibility to carry out the task as well as possible.

4. The development of a sense of belonging and a high sense of solidarity among employees.

5. Increased work efficiency and productivity of employees (Sutrisno, E, 2009).

\subsection{Work environment}

Work environment according to Nitisemito (1991) is everything that exists around the worker and can affect him in carrying out the tasks that are charged. Indicators of the work environment are as follows: coloring, cleanliness, lighting, air exchange, music, safety and noise.

\subsection{Education and Workshop}

In the Republic of Indonesia Government Regulation No.101 of 2000 article 1 what is meant by Education and Training is "the process of organizing teaching and learning in order to improve the ability of Civil Servants"

\section{5 performance}

Performance comes from the words Job Performance or Actual Performance (actual performance) or someone achieved. Understanding performance (work performance) is the work of the quality and quantity achieved by an employee in carrying out their duties in accordance with the responsibilities given to him (Mangkunegara, 2007)

\subsection{Results and Discussion}

\subsubsection{Multiple linear regression analysis}

Multiple linear regression analysis is one of the statistical methods, it is useful to see the effect of the pattern of relationships between one or more independent variables on the dependent variable and from the results of tests conducted in this study of the estimated model, it can be seen in the following table. 
Table 4.1 Multiple linear Regression Analysis

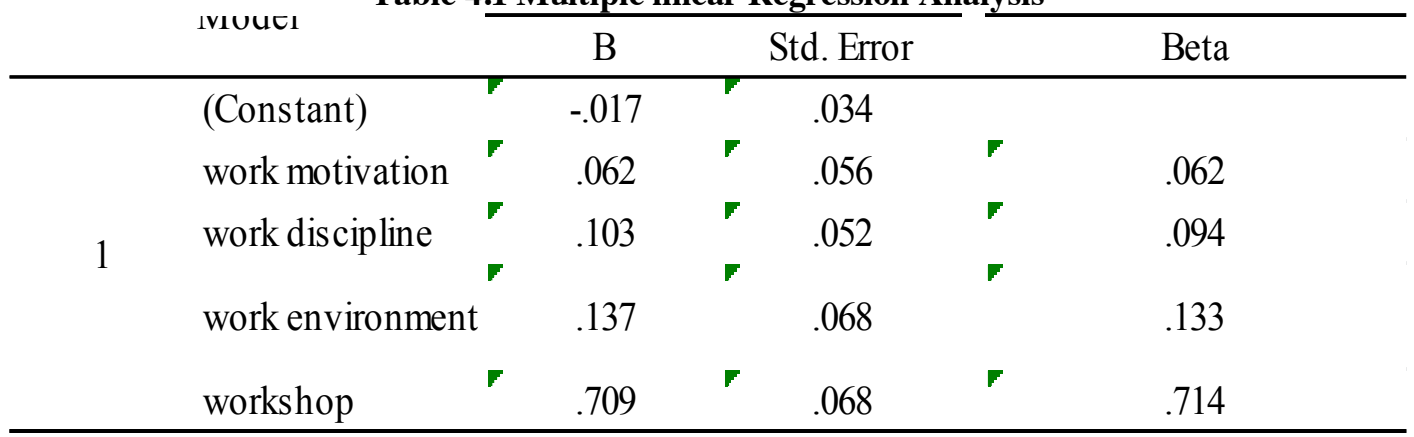

a. Dependent Variable: Kinerja PNS

Source: first Data in 2015

Based on the data analysis by SPSS, it was found that;

$\mathrm{Y}=\alpha+\beta_{1} \mathrm{X}_{1}+\beta_{2} \mathrm{X}_{2}+\beta_{3} \mathrm{X}_{3}+\beta_{4} \mathrm{X}_{4}+\mathrm{e}$

$Y=(-0,017)+0,062 X_{1}+0,103 X_{2}+0,137 X_{3}+0,709 X_{4}+e$

Information :

$\mathrm{X}_{1}=$ work motivation

$\mathrm{X}_{2}=$ work discipline

$\mathrm{X}_{3}=$ work environment

$\mathrm{X}_{4}=$ workshop

$\mathrm{Y}=$ civil servants' performance

Based on the regression equation, it can be explained as follows:

1. constants $\alpha$

the constants score is minus` $(-0,017)$ it is meaningless due to the independent variables $X_{1}, X_{2}, X_{3}$ and $X_{4}$ is not absolutely 0 .

2. Work motivation $\left(\mathrm{X}_{1}\right)$ on civil servants' performance (Beta $\left.\mathrm{Y}\right)$

Coefficient score for variable $\mathrm{X} 1$ or work motivation= 0,062 , it means that each improvement of a unit work motivation variable, variable beta $(\mathrm{Y})$ will raise 0,062 with assumption that the other independent variables is constant. Therefore it can be concluded that coefficient regression of work motivation variable has positive score in the influence of the quality of AMDAL document.

3. Work discipline $\left(\mathrm{X}_{2}\right)$ on civil servants' performance (Beta $\left.\mathrm{Y}\right)$

The coefficient score for variable $\mathrm{X} 2$ or work discipline is 0.103 , meaning that for every increase in one unit of work discipline variable, the beta variable $(\mathrm{Y})$ will increase by 0.103 assuming that the other independent variables in the regression model are fixed. The regression coefficient of the work discipline process variable appears to have a positive direction value in its effect on the civil servants' performance.

4. Work environment $\left(\mathrm{X}_{3}\right)$ on civil servants' performance (Beta $\left.\mathrm{Y}\right)$

The coefficient value for variable $\mathrm{X} 3$ or work environment is 0.137 , meaning that for every increase of one unit of work environment variable, the beta variable $(\mathrm{Y})$ will increase by 0.137 assuming that the other independent variables in the regression model are fixed. The regression coefficient of the work environment variable appears to have a positive direction value in its effect on civil servants' performance.

5. workshop $\left(\mathrm{X}_{4}\right)$ civil servants' performance (Beta $\mathrm{Y}$ )

The coefficient score for $\mathrm{X} 4$ or workshop variable is 0.709 , meaning that every increase of one unit of workshop variable, the beta variable $(\mathrm{Y})$ will increase by 0.709 assuming that the other independent variables in the regression model are fixed. The regression coefficient of the workshop variable appears to have a positive direction value in its effect on the civil servants' performance.

\subsection{2. determination coefficient $\left(\mathbf{R}^{2}\right)$}

The determination coefficient is determined by the adjusted $\mathrm{R}$ square value which essentially measures how far the ability of the variation of the independent variable in explaining the dependent variable. This coefficient value is between 0 and 1 , if the result approaches 0 , it means that the ability of the independent variables in explaining the variation of variables is very limited. 
But if the result approaches number 1 it means that the independent variables provide almost all the information needed to predict the variation of the dependent variable. Based on the calculation results it is known that work motivation, work discipline, work environment and workshop have an effect of 0.997 or $99.7 \%$ on the performance of civil servants and the remaining $0.3 \%$ is influenced by other variables not included in this study. Because the $\mathrm{r}$ square value of 0.993 or $99.3 \%$, it can be concluded that the ability of independent variables can provide almost all the information needed to predict variations in the dependent variable. Independent variables provide almost all the information needed to predict the variation of the dependent variable.

\subsubsection{Uji F (Uji Simultan) dan Uji t (Uji parsial)}

$F$ test is used to determine whether the independent variables simultaneously have a significant effect on the dependent variable, with the degree of trust used is 0.05 . This simultaneous test is if the calculated $F$ value is greater than the $F$ value according to the table then the alternative hypothesis, which states that all independent variables simultaneously have a significant effect on the dependent variable. ANOVA test shows that these four variables explain the variation of the performance of civil servants with $\mathrm{F}_{\text {count }} 3,611>\mathrm{F}_{\text {table }} 2,470$, or score sig $<0,05$, variable df $1=4$, df $2=95$, df $3=99$, so $\mathrm{H}_{1}$ is accepted and $\mathrm{H}_{0}$ is rejected, it means simultaneously work motivation, work discipline, work environment and workshop has significant influence towards Beta Y (civil servants' performance.

$\mathrm{T}$ test is a test used to find out whether the independent variables partially have a significant effect on the dependent variable. This study uses a significant degree of 0.05 . Based on the calculation results can be explained as follows:

\section{Work motivation variable}

The test results obtained for $\mathrm{t}$ score, the variable work motivation shows the score of $\mathrm{T}_{\text {table }} 1.097<\mathrm{T}_{\text {table }} 2.132$, H1 is rejected and $\mathrm{H} 0$ is accepted. These results can be interpreted that work motivation does not have a significant effect on the performance of civil servants, meaning that given work motivation does not result in changes in Employee Performance. These results indicate that employees remain focused on routine work without being influenced by work motivation.

2. work discipline variable

The result test obtained for $\mathrm{t}$ score work discipline variable shows $\mathrm{T}_{\text {count }} 1,962<\mathrm{T}_{\text {table }} 2,132$, so $\mathrm{H} 1$ is rejected and H0 is accepted. This result proved that work discipline has no significant influence towards civil servants' performance, it means by applying some regulations, it will not affect any changes to civil servants' performance. Simply, the civil servants just focus on their routine job.

3. work environment variable

The test result obtained score $\mathrm{T}$ for work environment variable and shows the score of $\mathrm{T}_{\text {count }} 2,006<\mathrm{T}_{\text {table }} 2,132$,so $\mathrm{H} 1$ is rejected and $\mathrm{H} 0$ accepted. This results mean that work environment has no significant influence towards civil servants' performance, yet it is concluded that by providing good work environment will not give any feedbacks to civil servants' changes. This result shows that the civil servants just stay focus on their routine job without influenced by work environment.

4. workshop variable

The test result obtained score $\mathrm{T}$ for workshop variable shows the score of $\mathrm{T}_{\text {count }} 10,463>\mathrm{T}_{\text {table }} 2,132$, so it means that workshophas influence on civil servants' performance or $\mathrm{H} 1$ is accepted and H0 is rejected. Regression coefficient shows positive significantly to civil servants' performance which means that the more workshop they got, the better performance they will have.

\section{Conclusions}

Based on the study conducted by questionnaire method to BAPEDAL civil servants Aceh Province, it could be concluded that;

1. motivation has no significant influence on civil servants' performance, it means that more motivation will not cause them to improve their performance.

2. discipline has no significant influence on civil servants' performance, it means that higher discipline will not affect them to improve their performance.

3. work environment has no significant influence on civil servants' performance, it means that better work environment will not affect significantly to their performance.

4. workshop has significant influence on civil servants' performance, it means, the more workshop the better quality of performance they have.

5. simultaneously, work motivation, work discipline, work environment, and workshop variables has significant influence on civil servants' performance.

\section{References}

Danim, Sudarwan. 2004. Motivasi, Kepemimpinan Dan Efektivitas Kelompok. Cetakan Pertama. Jakarta. PT. Rineka Cipta. Davis, K. \& Newstrom, J.W,. 1996. Perilaku dalam Organisasi, Edisi ketujuh. Jakarta :Penerbit Erlangga

Hutajulu, S. M., \& Supriyanto, S. (2013). Tinjauan Pelaksanaan Pelatihan Dan Pengembangan Karyawan Pada Pt. Inalum Kabupaten Batubara. Jurnal Bis-A: Jurnal Bisnis Administrasi, 2(2), 30-39.

Mangkunegara, A. P. (2007). Evaluasi Kinerja Sumber Daya Manusia, Cetakan ketiga. Bandung: Penerbit PT Refika Adi tama.

Nitisemito, A.S. (1991) Manajemen Personalia. Jakarta: Ghalia.

Peraturan Pemerintah Republik Indonesia No.101 tahun 2000

Sutrisno, E. (2009). Manajemen Sumber Daya Manusia. Jakarta: Kencana Prenada Media

Wibisono. (2003). Riset bisnis. Jakarta: PT. Gramedia Pustaka Utama. 